\title{
Por uma identidade cultural para Goiás: uma análise da revista Goianidade (1992)
}

\author{
For a cultural identity for Goiás: \\ an analysis of the magazine Goianidade (1992) \\ Rildo Bento de Souza*
}

\begin{abstract}
Resumo
A revista Goianidade foi editada em 1992 pela Associação Goiana de Imprensa, em única edição, e teve o objetivo de construir uma identidade cultural para Goiás, fomentando a ideia de pertencimento entre o cidadão e o seu lugar onde vive. 0 período em que a revista veio a público é muito interessante, uma vez que surgiu menos de cinco anos após dois grandes eventos que abalaram a população goiana: o acidente radioativo com o Césio-137, que ocorreu em 1987, em Goiânia, e a criação do Estado do Tocantins, a partir da divisão do território em 1988, com o advento da nova Constituição da República. O objetivo desse artigo é analisar o roteiro traçado pela revista para a criação de uma identidade cultural para Goiás a partir dos pressupostos de Stuart Hall. Outrossim, debateremos o contexto em que a revista foi criada e como que o texto sugere que a jovem capital, Goiânia, construída na década de 1930, reivindicou o protagonismo na formação e construção da identidade goiana. Ademais, discutiremos as lacunas deixadas pela revista ao recontar este passado, onde julgamos residir os estigmas da história de Goiás, quais sejam, a decadência, o isolamento, e o atraso.
\end{abstract}

Palavras-Chave: Identidade cultural; Goianidade; Goiás; Goiânia.

\begin{abstract}
The magazine Goianidade was published in 1992 by the Goiania Press Association, in a single edition, and aimed to build a cultural identity for Goiás, fostering the idea of belonging between the citizen and his place where he lives. The period in which the journal came to the public is very interesting, since it came less than five years after two major events that affected the population of Goiás: the radioactive accident with Césio-137, which occurred in 1987 in Goiânia,
\end{abstract}

\footnotetext{
*Doutor em História pela Universidade Federal de Goiás. Professor Adjunto do curso de Museologia da Universidade Federal de Goiás. E-mail: rildobento@gmail.com
} 
and the creation of the State of Tocantins, from the division of territory in 1988, with the advent of the new Constitution of the Republic. The objective of this article is to analyze the itinerary traced by the magazine for the creation of a cultural identity for Goiás from the assumptions of Stuart Hall. Also, we will discuss the context in which the magazine was created and how the text suggests that the young capital, Goiânia, built in the 1930s, claimed the leading role in the formation and construction of the identity of Goiás. In addition, we will discuss the gaps left by the magazine in recounting this past, where we believe the stigmata of the history of Goiás, such as decay, isolation, and backwardness, reside.

Keywords: Cultural Identity; Goianidade; Goiás; Goiânia.

\section{Introdução}

Em 1992 foi publicada pela Associação Goiana de Imprensa a Revista Goianidade. O título do editorial intitulado "Em defesa de uma Identidade Cultural" preocupa-se com os estereótipos sobre Goiás, principalmente por ser um estado agrícola. Esse preconceito, de acordo com a revista, era alimentado "de forma tola" em alguns setores da sociedade, "que julga incompatível a conquista de importância cultural por parte de uma sociedade vinculada a um tipo de contexto econômico no qual se realça o setor agrícola, como é o caso de Goiás, não encontra justificativa em parte alguma".

A finalidade da revista, portanto, era defender uma identidade cultural para Goiás. Mas qual o caminho trilhado pela revista para atingir esse objetivo? Em quais circunstâncias ela foi criada? Quais discursos presentes nessa narrativa e a quem ela servia? Esses são alguns dos questionamentos que tentaremos responder ao longo das próximas páginas. De acordo com Stuart Hall, "uma cultura nacional é um discurso", que "ao produzir sentidos sobre 'a nação', sentidos com os quais podemos nos identificar, constroem as identidades".

Outrossim, ao se perguntar como é contada a narrativa de uma cultura nacional, Hall expõe cinco elementos principais que pautam a identidade de uma nação, quais sejam, a narrativa da nação; a ênfase nas origens, na

\footnotetext{
${ }^{1}$ IMPRENSA, Associação Goiana de. Revista Goianidade. Goiânia: s/e, 1992, p. 03.

${ }^{2}$ HALL, Stuart. A Identidade Cultural na Pós-Modernidade. Rio de Janeiro: DP\&A editora, 2001, p. 50-51.
} 
continuidade, na tradição e na intemporalidade; a invenção das tradições; o mito fundacional; e a idéia de um povo ou folk puro, original. ${ }^{3}$ É através desses cinco elementos que estruturamos o nosso estudo; posteriormente, iremos contrapor os objetivos da revista Goianidade, com a tentativa de se construir uma identidade para Goiás.

\section{A Revista Goianidade e o seu contexto}

A revista Goianidade data do início da década de 1990, um período conturbado da história goiana. Dois fatos ocorridos no decorrer dos cinco anos anteriores à sua publicação, e que estigmatizaram o povo goiano, ressaltam a urgência em se estabelecer uma identidade, no sentido de evidenciar um sentimento de orgulho por parte de seus habitantes: 0 acidente radioativo envolvendo césio-137, que ocorreu em Goiânia em setembro de 1987, e a divisão do território dando origem ao Estado do Tocantins, por meio da Constituição de 1988, que veio a se concretizar no ano seguinte.

Em setembro de 1987, Goiânia, e por extensão, todo o Estado, atraíram a atenção de todo o mundo: a cidade era palco do maior desastre radiológico do planeta. Sua história pode ser resumida em poucas palavras: dois catadores de papel retiraram uma peça de chumbo de um aparelho de radioterapia, que estava abandonado desde a década de 1970, em um cômodo sem portas e sem janelas no meio de um terreno baldio, onde antes funcionava como parte da Santa Casa de Misericórdia, o Instituto Goiano de Radioterapia. Na casa de um dos catadores, a peça de chumbo foi aberta a marretadas, expondo as dezenove gramas de Cloreto de Césio-137. Logo após, venderam a peça para um ferro-velho próximo, cujo dono se interessou pela luminosidade oriunda do Césio. A partir de então, ele foi distribuído a várias pessoas. Das vítimas, quatro faleceram um mês após o acidente e centenas continuam com algum tipo de sequela até hoje.

Segundo a antropóloga Telma Camargo da Silva, o desastre envolvendo o Césio-137 "provocou transtornos na ordem cultural, política e econômica" em Goiânia. Houve uma intensa discriminação contra Goiás e, principalmente, contra os goianos. Produtos oriundos do Estado eram rejeitados nos mercados nacionais; houve cancelamento de conferências e encontros já previamente agendados para a capital; goianos eram recusados em viagens para outros Estados; os recursos financeiros do governo estadual foram canalizados para

${ }^{3}$ HALL, op. cit., 2001, p. 52-56. 
a descontaminação da cidade em detrimento de outras áreas. ${ }^{4}$ Nessa perspectiva, diante de tal cenário, podemos aventar que a população goiana sofreu um forte impacto no que se refere a sua identidade, naquilo que o liga ao território onde habita. A idéia de pertencimento, de pertencer a Goiânia, de orgulhar-se dela foi abalada.

A revista Goianidade, editada cinco anos depois do acidente, cita brevemente, em um dos artigos o referido episódio. O subtítulo é sugestivo: "Césio, nunca mais!”. Em dois parágrafos curtos há uma síntese do acidente e uma conclusão: "Hoje restam vítimas, deformações e nenhum culpado pela tragédia na cadeia”. Mais adiante em outro artigo sobre a Goiânia, há um registro que deve ser feito, até mesmo porque, de fato, conclui melhor e ainda responde àqueles que ainda temiam a capital de Goiás: "Uma jovem cidade com velhas lições para dar, como o episódio do césio-137, que soube muito bem superar". ${ }^{5}$

Mas será que Goiânia soube realmente superar o desastre? Para Silva, o período de 1987 a 1997 ocorreu "a descontaminação simbólica do desastre", através de uma "aliança estabelecida entre os setores nucleares e o Governo Estadual”; que por sua vez, "desautorizaram novas alegações de doença provocadas pela contaminação radioativa", além de deslegitimar "as experiências cotidianas de sofrimento das vítimas"; e por fim "apagaram ou ressignificaram as marcas do desastre impressas no espaço urbano". ${ }^{6}$

Desse modo, a cidade se purifica, ou seja, elimina qualquer ligação do seu espaço urbano com o desastre de $1987 .{ }^{7}$ Essa ligação entre o espaço e a construção de identidades foi analisada por Lúcia Lippi Oliveira, que a fez pautado no caso norte americano. Segundo a autora em meados do século XIX, "desenvolve-se e espalha-se a crença de que a natureza se opõe à civilização, e a virtude e a dignidade estão do lado da natureza". Com isso, "o romantismo e as idéias do transcendentalismo norte-americano se juntaram para produzir um movimento de defesa da natureza que estava se deteriorando

\footnotetext{
${ }^{4}$ SILVA, Telma Camargo da. "Desastre como processo: saberes, vulnerabilidade e sofrimento social no caso de Goiânia". In: LEIBING, Annette (org.) Tecnologias do Corpo: uma antropologia das medicinas no Brasil. Rio de Janeiro: Nau editora, 2004, p. 205.

${ }^{5}$ IMPRENSA, op. cit., p. 35-37.

${ }^{6}$ SILVA, op. cit., 2004, p. 207-208.

${ }^{7}$ Como parte da estratégia utilizada, podemos citar o numero 7 , da rua 57 , onde a peça de chumbo foi aberta, que foi apagado da sinalização urbana de Goiânia em 1988; o Centro de Cultura e Convenções, edificado em 1994, onde funcionava a Santa Casa de Misericórdia, não possui nenhuma referência ao desastre; e a emancipação do distrito de Abadia de Goiás, em 1995, que até então pertencia a Goiânia, para onde foram levados os rejeitos radioativos. (SILVA, Telma Camargo da. "As fronteiras das lembranças: memória corporificada, construção de identidades e purificação simbólica no caso de desastre radioativo". In: Vivência, no 28, 2005, p. 63 a 65).
} 
rapidamente" ${ }^{8}$ Goiânia, então em intenso processo de purificação, também se valeu da defesa e da preservação da natureza, utilizando o mesmo antagonismo: civilização, que recebeu a roupagem de progresso, e natureza. Nesta perspectiva:

(...) o acidente com o césio-137 contribuiu para que a cidade repudiasse suas características progressistas e se voltasse para uma postura pós-moderna (no sentido de crítica à ideologia do progresso). Desse modo, ela vai repudiar suas características de metrópole, tais como crescimento populacional, desenvolvimento industrial, verticalização, poluição ambiental. Assim, há uma mudança nos discursos dos administradores da cidade que agora utilizam como palavras-chaves na propaganda da cidade respeito ao meio ambiente, a qualidade de vida, a recuperação da memória histórica, etc. ${ }^{9}$

Dever-se-á, entretanto, considerar que Goiânia, cuja construção data da década de 1930, foi projetada para ser uma cidade moderna, ou seja, uma capital que "privilegiasse a saúde de seus habitantes". O então Interventor Federal Pedro Ludovico Teixeira (1891-1979), idealizador da capital, que era médico, almejava uma cidade plenamente atendida com abastecimento de água, redes de esgotos, coleta do lixo, e que "disporia também de parques, jardins, áreas destinadas a esportes e recreio, além de ruas e avenidas arborizadas". ${ }^{10}$ É esse ideal de cidade que será retomado na descontaminação simbólica do desastre com o césio-137.

(...) o projeto urbanístico de 1933 enfatiza a idéia de integrar indivíduos, natureza e a cidade moderna. Nessa perspectiva, o projeto original expressou a preocupação que os urbanistas tiveram com a conservação dos rios e dos bosques situados na nova área urbanizada. A re-apropriação feita pelo governo, no período de 1980 a 1990, da natureza como elemento de bem-estar urbano desconsiderou a qualidade da água dos rios, a melhoria do sistema de esgoto e a conservação da mata nativa e promoveu a plantação de flores no espaço urbano como expressão de sua preocupação com o meio ambiente. A ênfase dada pela administração municipal no cultivo de flores significou um esforço para desviar a atenção dos habitantes das áreas atingidas pela contaminação radioativa. De fato, enquanto alguns setores da cidade eram cobertos com canteiros floridos, atraindo a atenção dos turistas, os locais que foram contaminados pela radiação permaneciam abandonados, vazios e sujos ${ }^{11}$.

\footnotetext{
${ }^{8}$ OLIVEIRA, Lucia Lippi. “Representações Geográficas da Identidade Nacional - O caso norte-americano”. In: Americanos. Representações da identidade nacional no Brasil e nos EUA. Belo Horizonte: UFMG, 2000, p. 118. ${ }^{9}$ OLIVEIRA, Eliézer Cardoso de. Imagens e Mudança Cultural em Goiânia. Dissertação, mestrado em História. Goiânia: Universidade Federal de Goiás, 1999, p. 134

${ }^{10}$ FREITAS, Lena Castello Branco Ferreira de. “Goiânia: lócus privilegiado da saúde”. In (Org.). Saúde e doenças em Goiás: a medicina possível. Goiânia: Ed. UFG, 1999, p. 239.

${ }^{11}$ SILVA, op. cit., 2005, p. 64
} 
É essa imagem de cidade arborizada, florida, cheia de cores, completamente descontaminada do pesadelo que foi o desastre com césio-137 que a revista Goianidade enfatizou. No artigo intitulado "Do passado ao presente", por exemplo, há uma frase que sintetiza esse sentimento: "Goiânia hoje já existe no mapa do Brasil como uma das mais belas e limpas capitais". Mais adiante arremata: "Terra de mulher bonita e gente hospitaleira". ${ }^{12}$ Ou seja, o turista que quiser conhecer uma cidade com mulheres bonitas, gente hospitaleira, não precisa se preocupar com o desastre de 1987, Goiânia é uma capital limpa, termo este que possivelmente remete a limpeza pelo qual passou a cidade retirando, seja efetivamente, ou simbolicamente, qualquer vinculação entre ela e o episódio com o césio-137.

O outro fato importante para entendermos o contexto e a intencionalidade com que a revista Goianidade foi produzida é a criação do Estado do Tocantins em 1989. A questão das fronteiras do Estado sempre foi um assunto complexo na História de Goiás. Observando os mapas da Capitania e Província de Goiás ${ }^{13}$ nos séculos XVIII e XIX, constata-se que o território goiano sofreu perdas significativas. $\mathrm{O}$ traçado das fronteiras de Goiás ia muito além do atual: adentrava pelo território de Minas Gerais, incluindo o Triângulo Mineiro, e cidades importantes como Araxá; no lado oposto, Goiás ultrapassava as margens do Rio Araguaia, se prolongando pelo território de Mato Grosso; o mesmo acontecia ao norte, nos territórios do Grão-Pará e Maranhão. No final do século XIX e no século XX, as perdas se acentuaram. Primeiro foi a expedição chefiada pelo cientista Luís Cruls, que demarcara um território em pleno Estado de Goiás, que oferecia todas as condições para que fosse edificada a nova capital do país; fato que veio a se concretizar na década de 1950, pelas mãos do então presidente Juscelino Kubitscheck. E, por fim, a separação do norte, dando origem ao Estado do Tocantins. ${ }^{14}$

A revista Goianidade toca na polêmica questão das fronteiras do Estado no artigo "A modernidade está no mapa". Nele, as razões da perda do Triangulo Mineiro que deixou de ser goiano por um fato amoroso e não político, envolvendo a lendária Dona Beja; ${ }^{15}$ a escolha do território goiano para sediar a

\footnotetext{
${ }^{12}$ IMPRENSA, op. cit., p. 37.

${ }^{13}$ Os mapas que observamos se encontram em ROCHA, Leandro Mendes (org.). Atlas Histórico. Goiás PréColonial e Colonial. Goiânia: Editora do CECAB, 2001.

${ }^{14}$ Sobre esse assunto ver o estudo de: CAVALCANTE, Maria do Espírito Santo Rosa. 0 discurso autonomista do Tocantins. Goiânia: Ed. da UCG, 2003, especialmente a segunda parte do quarto capítulo.

15 "Curiosamente o Triângulo Mineiro deixou de fazer parte do território goiano em função não de um fato político, mas sim amoroso, após 50 anos de anexamento, de 1766 a 1816. À época o Ouvidor, vindo do Rio de Janeiro, Silveira Mota, apaixonou-se perdidamente por Ana Jacinta de São José (Dona Beja), natural de Araxá, raptando-a e assassinando dois
} 
nova Capital Federal; ${ }^{16}$ e a criação do Estado do Tocantins, ${ }^{17}$ são explicadas a partir do conformismo em relação às perdas territoriais. Isso fica explicito no último artigo da revista, intitulado "Ser Goiano", de autoria do escritor José Mendonça Teles:

Ser goiano é saber perder um pedaço de terra para Minas, mas não perder o direito de dizer também, uai, este negócio, este trem, quando as palavras atropelam no caminho da imaginação. (...) O bom goiano aceita a divisão do Estado, por entender que a alma goiana permanecerá eterna na saga do Tocantins. (...) Brasília em terras goianas é gesto de doação, é patriotismo. Simboliza poder. Mas o goiano não sai por aí contando vantagem. ${ }^{18}$

De acordo com Stuart Hall o discurso da cultura nacional "não é, assim, tão moderno como aparenta ser", uma vez que ele "constrói identidades que são colocadas, de modo ambíguo, entre o passado e o futuro". Ou seja, há constantemente uma volta ao passado, ao "tempo perdido", a uma época de glória. ${ }^{19}$ Editada cinco anos após o acidente com o Césio-137 e três anos da criação do Estado do Tocantins, a revista Goianidade cumpre esse papel de relembrar o tempo anterior ao período desabonador, uma vez que ideia de pertencimento a um lugar fora rompido. No primeiro, o preconceito vindo de várias partes e a vergonha de ser goiano; no segundo, uma nova identidade que é construída devido à divisão do Estado.

O que liga os dois fatos e deixa a trama ainda mais imbricada é a questão política que os perpassou. Se no desastre com o césio-137, montou-se uma estrutura capaz de maquiar a cidade e purificá-la simbolicamente da tragédia, na separação do Tocantins grupos políticos com o intuito de se afirmarem

de seus familiares. Acontece que ele era casado - descobrindo isso a sociedade resolveu denunciá-lo por concubinato. Eis então que, para escapar, Silveira da Mota colocou-se ao lado do desmembramento do território da capitania, tirando dela a jurisdição civil e criminal" (IMPRENSA, op. cit., p. 47).

16 "A nova Capital Federal chega para sedimentar a ação colonizadora do Centro-Oeste, que desde 1728 enfrentou o desafio de fomentar seu espaço político territorial. Com a construção de Brasilia, em 1960, por obra de Juscelino Kubitschek, Goiás enfim consegue se firmar como potência independente" (IMPRENSA, op. cit., p. 49).

17 "(...) a recente separação de Goiás e Tocantins (criado em 5 de outubro de 1989) que quebrou uma hegemonia política mais do que secular. Embora questionada por muitos, a divisão do Estado se fez e os primeiros resultados, como a criação da nova capital Palmas, demonstram que era necessária a divisão, objetivando-se dinamizar e desenvolver a região. (...) com o mapa do Brasil já demarcado, Goiás vem enfrentar novamente o desafio da divisão em 1989, com a criação do Estado do Tocantins. Como alegação principal a necessidade da expansão da fronteira agrícola, que dada a longa configuração territorial acabou por gerar um bolsão de desenvolvimento ao sul em detrimento da região Norte. Hoje, decorridos três anos, ainda há quem oponha resistência à divisão. Assim Goiás se aproxima do ano 2000, com uma nova configuração territorial, na qual os políticos de hoje, como os de outrora, persistem no ideal de um Estado moderno" (IMPRENSA, op. cit., p. 49).

${ }^{18}$ IMPRENSA, op. cit.. Goiânia: s/e, 1992, p. 162.

${ }^{19}$ HALL, op. cit., 2001, p. 50-56. 
no poder criaram uma memória histórica daquela região justificando a sua independência. ${ }^{20}$ Por isso, o período em que a revista foi editada não poderia ser mais frutífero para as discussões a respeito da identidade goiana. Era o momento de resgatar o orgulho de ser goiano, de valorizar as tradições, o meio ambiente, o povo, a arquitetura, o artesanato, a culinária, os artistas, enfim, o próprio sentimento de goianidade.

\section{A narrativa da história do estado}

A narrativa da história do povo goiano e seus feitos são abordados pela revista Goianidade, ao longo dos seus vinte e oito artigos. Para a elaboração destes, seus redatores se pautaram, em sua maioria, em livros memorialísticos, refletindo a escassa produção acadêmica do período, que só veio a se fortalecer na década de 1990 em diante. Visando a cronologia dos fatos, a revista abre com o artigo intitulado "Primeiros Habitantes do Planalto Central", logo em seguida uma síntese da matéria: "A rigor, os primitivos de Goiás não eram goianos, e isto por um bom e decisivo motivo: há 11 mil anos não havia Goiás, não havia Brasil, não havia América ou Europa". Ou seja, a revista foi buscar nos grupos humanos que viviam nesse território, não a gênese do povo goiano, mas porque "a abundancia de sítios arqueológicos datados desta época foi o bastante para colocar o Estado no centro das discussões arqueológicas mundiais". ${ }^{21}$ Isso evidencia a preocupação em ressaltar o orgulho da terra, cuja história se inicia bem antes das primeiras expedições dos bandeirantes; por outro lado, as três palavras "discussões arqueológicas mundiais", podem ser entendidas como um instigante relato de progresso, uma vez que Goiás chama a atenção do mundo, agora por um fato que é digno de orgulho e não de repulsa como foi o desastre com o césio.

A revista segue, no segundo artigo, enfocando os índios, no sugestivo título "Tribos da Resistência". Nele é discutida a forma cruel com que os índios foram colonizados, o trabalho, o extermínio, e a redução dos seus espaços. Alguns povos indígenas foram citados como os Avá-Canoeiro, os Krahô, os Caiapó, e os Xerente, e como esses grupos ainda hoje lidam com o branco. ${ }^{22}$

No artigo seguinte, "Dos Quilombos fez-se Kalunga", abre-se espaço para o negro da comunidade Kalunga, um grupo de quilombolas que se

\footnotetext{
${ }^{20}$ RIBEIRO, Fabrizio de Almeida. A Invenção do Tocantins: memória, história e representação. Dissertação, mestrado em História Goiânia: Universidade Federal de Goiás, 2001.

${ }^{21}$ IMPRENSA, op. cit., p. 05-08.

${ }^{22}$ IMPRENSA, op. cit., p. 09-11.
} 
refugiaram no norte do território goiano. Nesse lugar, mantiveram-se isolados até os anos de 1980. Os Kalunga ainda conservam antigos hábitos, apesar de manterem intercâmbio com algumas cidades. ${ }^{23}$

Posteriormente, entra em cena "A Odisséia do Ouro". Todavia, para tornar o texto ainda mais parecido com uma saga há a seguinte comparação: "Os povoados cresceram ao compasso dos interesses dos bandeirantes paulistas, que se lançaram numa aventura pelos sertões comparável às viagens dos grandes navegadores". ${ }^{24}$ Este artigo será analisado no próximo item, que se dedica ao mito fundacional.

Contudo, esses quatro artigos iniciais da revista são inquietantes, primeiro porque enfocam os primeiros habitantes do que viria a ser o território goiano, depois descreve os índios, os negros, e por fim, em decorrência do ouro que aqui havia, os brancos. A ordem é interessante, mas cronologicamente não é a correta. $O$ artigo dedicado aos negros é anterior que a chegada dos brancos. Ao analisar cada grupo separadamente a revista produziu um sentido histórico confuso e controverso.

Ademais, de acordo com Hall, por mais que os membros de determinada nação sejam diferentes, "uma cultura nacional busca unificá-los numa identidade cultural, para representá-los todos como pertencendo à mesma e grande família nacional". Por fim, conclui "uma cultura nacional nunca foi um simples ponto de lealdade, união e identificação simbólica. Ela é também uma estrutura de poder cultural". ${ }^{25}$

Outrossim, primeiro identifica-se o diferente e depois congrega a todos sob uma mesma identidade, por mais que suas diferenças culturais sejam ressaltadas, como aconteceu no segundo artigo que abordou os índios, e no terceiro que abordou os negros, tal fato não ocorre com os brancos. Pelo discurso da revista, percebe-se que a intenção é de ressaltar o branco como o grupo hegemônico, ou seja, o que congregou, em torno de si, todos os outros. Há, portanto, uma valorização de determinado grupo, no caso o branco, em detrimento dos outros dois, o índio e o negro. ${ }^{26}$

\footnotetext{
${ }^{23}$ IMPRENSA, op. cit., p. 12-13.

${ }^{24}$ IMPRENSA, op. cit., p. 15.

${ }^{25}$ HALL, op. cit., 2001, p. 59.

${ }^{26} \mathrm{~A}$ forma como a revista Goianidade abordou esse tema lembra muito o seguinte fato: logo após fundado, em 1838, o Instituto Histórico e Geográfico Brasileiro lançou um concurso para saber sobre o caráter nacional brasileiro, uma tese que orientasse o sentido de História do Brasil; a vencedora foi a tese do naturalista alemão Karl Von Martius, que afirmou que o Brasil era o resultado da fusão de três "raças": branca, negra e índia. Nesse tratado, "que serviu de guia a respeito de 'como se deve escrever a história do Brasil', o tema do contato das três raças é explorado de maneira exemplar. Nele, a contribuição portuguesa para a
} 
A narrativa prossegue através das "Expedições Históricas", onde são citados os viajantes que escreveram sobre Goiás ao longo dos séculos. ${ }^{27}$ No artigo seguinte, o "Patrimônio Monumental" ganha às páginas com fotografias de antigos casarões. "Os bons frutos da nossa árvore genealógica" onde são expostas as principais famílias goianas é o artigo posterior. A saga prossegue com o meio ambiente nos artigos "Muita riqueza para um só lugar", uma verdadeira ode ufanista ao cerrado, e "Reservas de Vida" que trata dos

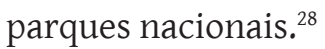

A saga do Estado avança sobre a construção de Goiânia, e enfim desembarcamos n' "A capital do Futuro", que conta a história da jovem capital de Goiás. Com esse artigo, a revista expõe o seu maior deslize: a história do Estado é contada no período Colonial e depois já passa para a República. O século XIX é citado brevemente quando fala dos viajantes que aqui estiveram. A revista reflete a falta de pesquisas acadêmicas em 1992 sobre o período Imperial. Pois bem, do início do século XIX à Goiânia há um salto de mais de um século, ou seja, a revista apenas refletiu desse modo, a dificuldade da pesquisa acadêmica de fazer eco na sociedade e também o número reduzido de pesquisa sobre esse assunto. Como afirmamos anteriormente, somente na década de 1990 ganhará vulto a pesquisa histórica sobre Goiás. ${ }^{29} \mathrm{O}$ que podemos aventar é que há um esforço em preencher essa lacuna com artigos exaltando as famílias, a arquitetura e o meio ambiente. A ausência desse período na revista Goianidade será abordada no último item deste ensaio.

Nos artigos seguintes a revista se dedica a vida social de Goiânia, aos principais expoentes da história de Goiás, o "Desenvolvimento Passo a Passo", com grandes obras sendo construídas, a economia se fortalecendo, e a perspectiva para um futuro promissor. Manchetes animadoras estamparam as páginas

formação da nacionalidade brasileira é associada a instituições políticas, econômicas e religiosas; em outras palavras, às formas de vida civilizadas. Já a contribuição dos negros é apresentada de maneira contraditória, havendo sucintas alusões aos conhecimentos dos africanos em relação à natureza e, ao mesmo tempo, a seus preconceitos e superstições. [...] o que faria do Brasil uma sociedade diferente da portuguesa não seria propriamente a presença africana (...) mas sim a indígena. Em relação a este seguimento, a posição de Martius foi a de não mencionar uma contribuição, mas sim indicar que eles eram 'ruínas de povos', ou seja, descendiam de uma antiga civilização que teria migrado para o Novo Mundo e entrado em decadência, regredindo a selvageria". (DEL PRIORE, Mary; Venancio. Uma breve história do Brasil. São Paulo: Editora Planeta do Brasil, 2010, p. 174).

${ }^{27}$ Na primeira metade do século XIX, percorreu a Província de Goiás os seguintes viajantes naturalistas: o francês Augustin François César Prouvensal de Saint-Hilaire; o austríaco Joahann Emmanuel Pohl; o português Luiz D'Alincourt; o inglês Willian John Burchell; o escocês George Gardner e o francês Castelnau.

${ }^{28}$ IMPRENSA, op. cit., 1992.

${ }^{29}$ SILVA, Rogério Chaves da. Reflexões sobre o "fazer histórico": uma história da historiografia em (sobre) Goiás (da década de 1920 à de 1990). Tese, doutorado em História. Goiânia: Universidade Federal de Goiás, 2015. 
da Goianidade, como: "Fábricas de Progresso", "Crescimento das Indústrias", "Comércio Registra Lucro Social", "Empresário de Sucesso".

Curiosamente, no artigo intitulado "Goiás em Três Tempos", os considerados três maiores líderes da história de Goiás dividem a mesma página com os seus feitos: Bartolomeu Bueno, bandeirante que descobriu as jazidas de ouro, possibilitando a colonização da região; Pedro Ludovico, idealizador e construtor de Goiânia; e, por fim, Íris Rezende Machado, então governador do Estado. Os três são tratados como mitos pela revista. É interessante destacar que a revista Goianidade queria transmitir a imagem de que vivia no auge do progresso, e o então governador Íris Rezende fazia uma administração progressista, dinâmica, e moderna. Igualmente, a revista queria perpetuar a idéia de que o Estado desbravado pela astúcia do bandeirante, ficou sem um passado relevante até Pedro Ludovico a quem é creditado a construção de Goiânia, e posteriormente, a história ganhava um novo fôlego com Íris Rezende, fazendo jus a modernidade e ao progresso tão ansiado pelo povo goiano. Isso condiz com o sentido de história empregado pela revista, excluindo o século XIX e a Primeira República.

Destarte, a saga do Estado prossegue com os "Desafios do Ensino", onde é descrito o sistema educacional de Goiás; os "Anos Dourados do Lyceu”, e o "Reduto de Normalistas" - o Instituto de Educação de Goiás; “Uma Instituição que Merece Respeito" sobre a Universidade Católica de Goiás; e "Pesquisa da Realidade Regional", sobre a Universidade Federal de Goiás, completam a lista sobre esse assunto. Em "Operação Saúde" há um balanço da medicina praticada em Goiás, ressaltando os principais expoentes dessa área. Os "Avanços da Ciência" afirmava orgulhosamente que Goiás detinha o conhecimento de procedimentos especializados no campo médico.

Stuart Hall argumenta que a narrativa da nação "dá significado e importância à nossa monótona existência, conectando nossas vidas cotidianas como um destino nacional que preexiste a nós e continua existindo após nossa morte" ${ }^{30}$ Todos os artigos citados até agora convergem para este objetivo. Apesar de serem formados por grupos de pessoas diferentes, eles se entrecruzaram numa mesma história, que caminhou, que paralelamente prosperou, e cuja intenção é de um progresso maior. Ou seja, há um enfoque nas origens, um balanço do que foi feito, do que está sendo feito, e do que poderá ser feito. Ou seja, a narrativa do território goiano e do seu povo se interliga em face de uma idéia de continuidade e progresso.

${ }^{30}$ HALL, op. cit., 2001, p. 52. 


\section{Sobre mitos e heróis}

Toda narrativa que se preze, ou seja, aquelas que são cuidadosamente talhadas para se aproximarem de um épico, concentram na figura do herói os seus mais retumbantes adjetivos. De acordo com Hall, o mito fundacional é "uma estória que localiza a origem da nação, do povo e de seu caráter nacional num passado tão distante que eles se perdem nas brumas do tempo, não do tempo 'real', mas de um tempo 'mítico'”. ${ }^{1}$

Em Goiás não foi diferente; o povo precisava de seus heróis, de pessoas a quem se espelhar, de trajetórias de vida que foram endossadas e sacralizadas pela memória. Na "Odisséia do Ouro", como na de Homero, Goiás necessitava de seu Ulisses (Odisseu), porém este não regressava da Guerra de Tróia, e sim, adentrava bravamente os territórios inexplorados dos sertões com suas bandeiras. ${ }^{32}$ De acordo com a narrativa da Goianidade, o herói em Goiás tem nome e sobrenome: Bartolomeu Bueno da Silva, o filho, a quem é atribuído a fundação da antiga capital do Estado, Vila Boa, posteriormente Cidade de Goiás.

Este tema foi amplamente discutido pelo historiador Antônio César Caldas Pinheiro, que através das "crônicas perceber-se-á o cuidadoso arranjo construído para se demonstrar a heroicidade desses primeiros povoadores, construindo um enredo no qual terá um papel preponderante a figura mitificada do segundo Anhanguera". ${ }^{33} \mathrm{O}$ objetivo dos bandeirantes era retirar o precioso metal que emanava fartamente no leito dos rios. Ambicionando fortuna, esses homens não se intimidavam ante os territórios desconhecidos dos então temidos índios Goiases.

A atração do ouro criava uma espécie de força motivadora capaz de superar obstáculos como percorrer longas distâncias a pé, passando por rios, cachoeiras, matas espessas, animais ferozes, índios hostis e submetendo-se a doenças. Na efervescência de movimento visando a penetração pelo interior do Brasil, há registros de que o bandeirante Bartolomeu Bueno da Silva estivera com o pai em terras goianas pela primeira vez em $1674 .{ }^{34}$

\footnotetext{
${ }^{31}$ HALL, op. cit., 2001, p. 54-55.

32 "A bandeira paulista era um misto de expedição militar e sociedade comercial financiada por abastados escravistas. Mais tarde, depois de descobertas as minas nos sertões interiores, organizaram-se as monções, ligações precárias compostas de tropas de muares, jangadas e canoas, objetivando o abastecimento dos arraiais. Formam-se então as correntes migratórias de povoamento, com movimentos semelhantes às frentes de expansão" (ROCHA, op. cit., p. 27).

${ }^{33}$ PINHEIRO, Antonio César Caldas. Os tempos míticos das cidades goianas: mitos de origem e invenção de tradições. Dissertação, mestrado em História. Goiânia: Universidade Federal de Goiás, 2003, p. 20.

${ }^{34}$ IMPRENSA, op. cit., p. 16.
} 
Inicia-se assim a saga de Bartolomeu Bueno da Silva, que quarenta anos, e várias tentativas depois, acha o lugar encontrado pelo seu pai, ao sopé da Serra Dourada, cortado pelo Rio Vermelho. "Por exigência da febre do ouro, o bandeirante Bueno funda o primeiro núcleo populacional de que se tem notícia - o arraial de Sant'Anna [...] Surge, assim, o embrião da futura capital do Estado". ${ }^{35}$ Ademais, a esperança da riqueza contagiava a todos que visavam fazê-lo com o ouro de Goiás, com isso aportavam inúmeros aventureiros, criando, consequentemente, vários arraiais e povoados, como Barra, Santa Rita e Meia Ponte. ${ }^{36}$

A construção mitificada da figura de Bartolomeu Bueno da Silva, segundo Pinheiro, data quinze anos após o seu falecimento em 19 de setembro de 1740, numa carta escrita pelo secretário da capitania de Goiás, Ângelo dos Santos Cardoso dirigida ao secretário de estado da Marinha e Ultramar, Diogo de Mendonça Corte Real. O referido secretário que chegou a Goiás em 1749, narra a descoberta das Minas e a história de seu descobridor colocando-o às vésperas da sua morte:

(...) com a provecta idade de 106 anos, gozando de perfeita saúde e ágil. Também acena que ele era um praticante da religião, freqüentando os sacramentos, indo pelos próprios pés à igreja receber a extrema-unção, visitando pela última vez todos os moradores como se soubesse o dia da sua morte e se preparasse para ela. Colocando-o em idade tão avançada, mas em seu perfeito juízo e no vigor de suas forças, talvez o narrador queria passar justamente a imagem construída do herói desbravador de Goiás. ${ }^{37}$

O autor questiona o porquê da exaltação da figura de Bartolomeu, aventando a hipótese de que era necessário "para se criar um sentimento de identidade, no que tange ao pertencimento a uma sociedade nascida da vontade de um homem, herói, descobridor de riquezas e fundador da capital da capitania". ${ }^{38}$ Para completar a trajetória do herói, consequentemente houve o surgimento do mito:

(...) Bartolomeu Bueno, que depois de "descobrir" as riquezas de Goiás, morreu pobre, esquecido, ficando, porém, na memória da capitania, aureolado como o descobridor e fundador de sua capital. Evidencia-se com isso um traço comum nas construções desse jaez, riqueza-empobrecimento, do reconhecimento

\footnotetext{
${ }^{35}$ IMPRENSA, op. cit., p. 16.

${ }^{36}$ Atualmente esses povoados são conhecidos com os respectivos nomes: Buenolândia, Pontalina e Pirenópolis.

${ }^{37}$ PINHEIRO, op. cit., p. 26.

${ }^{38}$ PINHEIRO, op. cit., p. 26.
} 
dos feitos heróicos-ingratidão, o que favorece a sedimentação do mito e sua conservação nas memórias em razão da teluricidade do tema e a comoção que engendra nos receptores. ${ }^{39}$

Outrossim, a revista evidencia que todo o progresso que Goiás vivenciou no século XX, principalmente a partir da construção de Goiânia, que enfocaremos mais adiante, tem uma origem, nasceu de um sonho, de um ideal. A saga de Bartolomeu Bueno que não desistiu de encontrar a terra que seus olhos viram quando menino, o reconhecimento de seus feitos, e o fim dramático, pobre e esquecido, como tem que ser a história dos grandes heróis, forjou uma identidade comum para Goiás. A partir da sua incursão pelos ríspidos sertões, nasceu a história do Estado, e a ela foram acrescentados o índio e negro, que no referido artigo da Goianidade, "A Odisséia do Ouro", compartilham as mesmas páginas, os mesmos parágrafos, mas não o mesmo destino.

\section{As tradições}

Um dos pilares da construção das identidades é o conjunto de tradições de um determinado povo. Elas remontam a um passado distante, porém podem ter sido inventadas, ou seja, criadas justamente com o objetivo de produzir essa dada identidade.

Tradições que parecem ou são consideradas antigas são bastante recentes, quando não são inventadas. (...) Por "tradição inventada" entende-se um conjunto de práticas, normalmente reguladas por regras tácita ou abertamente aceitas; tais práticas, de natureza ritual ou simbólica, visam inculcar certos valores e normas de comportamento através da repetição, o que implica, automaticamente: uma continuidade em relação ao passado. Aliás, sempre que possível, tenta-se estabelecer continuidade com um passado histórico apropriado. $^{40}$

Stuart Hall define tradição como um "cordão umbilical”, “imutável e atemporal" que liga "ao passado o futuro e o presente numa linha ininterrupta". ${ }^{41}$ Nesta perspectiva, Goiás possui várias manifestações, seja de caráter religioso, popular ou folclórico que se tornaram tradição no Estado; ou seja, algo que une determinado grupo de pessoas, como a folia de reis de Jaraguá; a festa do Divino Pai Eterno em Trindade; as cavalhadas de Pirenópolis; as congadas de Catalão; a catira, em várias cidades do interior,

\footnotetext{
${ }^{39}$ PINHEIRO, op. cit., p. 27.

${ }^{40}$ HOBSBAWN, Eric; RANGER, Terence. (Orgs.) A invenção das tradições. Rio de Janeiro: Paz e Terra, 1997, p. 09.

${ }^{41}$ HALL, Stuart. "Pensando a Diáspora. Reflexões sobre a terra no exterior". In: . Da Diáspora. Identidades e Mediações Culturais. Belo Horizonte: Editora UFMG; Brasília: Representações da UNESCO no Brasil, $2003,29$.
} 
etc. Todas essas manifestações são abordadas pela revista Goianidade como símbolos da cultura goiana.

Dentre essas diversas manifestações elegemos uma que se enquadra na definição de Tradição Inventada exposta acima: a Procissão do Fogaréu que ocorre na Cidade de Goiás durante a Semana Santa. O título do artigo é "Louvações Folclóricas", onde são abordadas tanto a Procissão do Fogaréu, quanto a Romaria de Trindade. É interessante que essas duas manifestações religiosas dividam um mesmo artigo sob o título que inclui a palavra folclórica.

Não consta no artigo quando a Procissão do Fogaréu surgiu, apenas remonta à sua grandiosidade; já na Romaria de Trindade resta a dúvida: "Há quem diga que a Romaria do Divino Pai Eterno, realizada todos os anos no mês de julho, seja a mais antiga de Goiás, apesar de não se saber ao certo a data da sua origem". ${ }^{42}$ Entretanto, é conhecido que a festa do Divino Pai Eterno surgiu por volta de $1840 .{ }^{43}$ A intenção do autor, quando escreve "há quem diga", já sugere que não há certeza, ou seja, a festa pode não ser a mais antiga de Goiás, ou pior, pode ser muito recente. Contudo, se analisarmos a Procissão do Fogaréu vemos que essa festa sim, data da segunda metade do século XX, e que está inserida num contexto maior: a transferência da capital.

Membros da população vilaboense ressentidos com a transferência da capital sentiram uma "crise de identidade". (...) depois que a cidade deixou de ser a capital, perdeu a proeminência que havia conquistado (...) e essa situação os deixou preocupados. Decidiram realizar eventos que atraíssem a atenção das pessoas. Assim, ao longo dos anos, foram criando valores culturais e fixando tradições. Isso conferiu a Goiás uma identidade. ${ }^{44}$

A Procissão do Fogaréu, portanto, é fruto de um processo que se iniciou com uma "crise de identidade", ou seja, não havia manifestações emblemáticas que fossem capazes de aglutinar as pessoas. Em decorrência disso a Organização Vilaboense de Artes e Tradições - OVAT iniciou a dramatização da procissão a partir de 1967.

A OVAT começou a levantar as festividades religiosas. (...) nós descobrimos que o fundador da Irmandade dos Passos, (...) foi o Pe Perestelo de Vasconcelos Espíndola, um espanhol. Durante essa história, saiu a Procissão do Fogaréu, com

\footnotetext{
${ }^{42}$ IMPRENSA, PINHEIRO, op. cit., p. 128.

${ }^{43}$ SANTOS, Miguel Archângelo Nogueira dos. Trindade de Goiás: uma cidade santuário. Conjunturas de um fenômeno religioso no Centro-Oeste brasileiro. Dissertação, mestrado em História. Goiânia: Universidade Federal de Goiás, 1978; DEUS, Maria Socorro de. Romeiros de Goiás: a romaria de Trindade no século XX. Dissertação, mestrado em História. Goiânia: Universidade Federal de Goiás, 2000.

${ }^{44}$ CARNEIRO, Keley Cristina. Cartografia de Goiás: Patrimônio, Festa e Memórias. Dissertação, mestrado em História. Goiânia: Universidade Federal de Goiás, 2005, p. 52.
} 
encapuzados e tal, que deixou de ser levada, desapareceu como tempo e tal. E nós começamos a reviver isso historicamente e pegamos que o Pe Perestelo tinha estado aqui justamente neste período de 1745. Então foi presumido que seja ele o introdutor de toda essa cerimônia que, se você comparar com a tradição espanhola vai bater. (...) Aí então atribuímos a ele, sabemos que ele foi o fundador da Irmandade do Passos. Também pusemos a data da irmandade em 1745 e a procissão iniciando nesta data. Tudo começando em 1745, que era um marco que nós tínhamos, um marco inicial registrado. ${ }^{45}$

Podemos aventar, a partir deste depoimento que a Procissão do Fogaréu, criada na década de 1960, está pautada em deduções sobre um passado que está sendo revivido. 0 que se pode presumir nas entrelinhas é que a procissão não foi criada e sim retomada, mesmo sem comprovações históricas contundentes de que ela realmente alguma vez ocorreu no passado. A tradição inventada da Procissão do Fogaréu remete a um passado longínquo, ou seja, para a revista é algo tipicamente goiano, cujas raízes estão cravadas no século XVIII. Por isso quando ao descrever a procissão o artigo não cita a sua origem porque a própria narrativa já constrói essa imagem de antigo para o leitor. Isso fica evidente no primeiro parágrafo:

Emparedada pela Serra Dourada e cortada pelo famoso Rio Vermelho, a cidade de Goiás também serve de cenário para espetaculares festas religiosas. As comemorações da Semana Santa na histórica Vila Boa, nome dos antigos tempos de capital do Estado, são das mais célebres, não apenas de Goiás mas de todo o Brasil. É nesse período que a bela paisagem colonial da cidade serve de moldura para um impressionante teatro popular, que começa na quartafeira, com a tradicional Procissão do Fogaréu, e só termina no domingo, com a queima do Judas e o começo da Folia do Divino. ${ }^{46}$

O texto acima é retumbante, notam-se as palavras-chaves para incutir no leitor a idéia de um passado remoto: "histórica Vila Boa", "antigos tempos de capital do Estado", "bela paisagem colonial”, e "tradicional Procissão do Fogaréu”. Com isso não é necessário nem mesmo ressaltar a data, a idéia de antigo já está implícito. Entretanto, quando o artigo se dedica a Romaria de Trindade fica a dúvida, como expusemos acima. Podemos aventar que o interesse do autor é transmitir uma mensagem simples: a Procissão do Fogaréu pode ser mais antiga que a Romaria de Trindade, embora nesta última tenha uma idéia de continuidade.

Dever-se-á, entretanto, considerar o conceito de tradição inventada abordado por Hobsbawm e Ranger que se referem a uma "continuidade com

\footnotetext{
${ }^{45}$ Depoimento de Elder Camargo dos Passos feito à Andréa Delgado, apud CARNEIRO, op. cit., p. 62. ${ }^{46}$ IMPRENSA, op. cit., p. 128.
} 
um passado histórico apropriado"; ou seja, a Procissão do Fogaréu foi criada na década de 1960, mas para lhe conferir o status de uma tradição, procurou-se um fato histórico, a fundação da Irmandade de Nosso Senhor dos Passos, e a partir daí desenvolveu-se a idéia de uma continuidade com esse passado, agora retomado. Porém, o retomado não fica explicito na revista e o que se pressupõe é que desde 1745, anualmente, a procissão é realizada, o que não deixa de ser uma manipulação das tradições de um povo, visando um objetivo, qual seja, o de criar uma identidade para a cidade de Goiás, que enfrentava um período de "decadência" cultural devido à transferência da capital para Goiânia e, a partir da revista, disseminar essa tradição para o restante do Estado.

\section{O povo goiano ideal}

Mas afinal, que tipo de gente é essa que se perde por esses caminhos que cortam o chão de Goiás? Quem são essas pessoas que a revista Goianidade pretende fazê-los sentirem-se goianos? Se as respostas são vagas, peço licença poética para colocar, quase por inteiro, um texto do literato José Mendonça Teles publicado na revista, sobre o sentimento de "Ser Goiano".

Ser goiano é carregar uma tristeza telúrica num coração aberto de sorrisos. É ser dócil e falante, impetuoso e tímido. É dar uma galinha para não entrar na briga e um nelore para não sair dela. É amar o passado, a história, as tradições, sem desprezar o moderno. É ter latifúndio e viver simplório, comer pequi, guariroba, galinhada e feijoada, e não estar nem aí para os pratos de fora. (...) O goiano da gema vive na cidade com um carro-de-boi cantando na memória. Acredita na panela cheia, mesmo quando a refeição se resume em abobrinha com quiabo. Lê poemas de Cora Coralina e sente na eterna juventude. Ser goiano é saber cantar música caipira e conversar com Beethoven, Chopin, Tchaikovsky e Carlos Gomes. É acreditar no sertão como um ser tão próximo, tão dentro da alma. É carregar um eterno monjolo no coração e ouvir um berrante tocando longe, bem perto do sentimento. Ser goiano é possuir um roçado e sentir-se um plantador de soja, tal o amor à terra que lhe acaricia os pés. É dar tapinha nas costas do amigo, mesmo quando esse amigo já lhe passou uma rasteira. 0 goiano de pé-rachado não despreza uma pamonhada e teima em dizer ei, trem bão, ao ver a felicidade passar na janela, e exclama viche, quando se assusta com a presença dela. Ser goiano é botar nos pés uma botina ringideira e dirigir tratores pelas ruas da cidade. É beber caipirinha no tira-gosto da tarde, com cerveja na eterna saideira. É fabricar rapadura, ter um passopreto nos olhos e um santo por devoção. O goiano histórico sabe que o Araguaia não passa de um "corgo", tal a familiaridade com os rios. Vive em palacetes e se exila nos botecos da esquina. Chupa jabuticaba, come bolo de arroz e toma licor de jenipapo. É machista, mas deixa que a mulher tome conta de casa. (...) Ser goiano é saber fundar cidades. É pisar no Universo sem tirar os pés deste chão-parado. É cultivar a goianidade como herança maior. É ser 
justo, honesto, religioso e amante da liberdade. (...) Ser goiano é olhar para a lua e sonhar, pensar que é queijo e continuar sonhado, pois entre o queijo e o beijo, a solução goiana é uma rima. ${ }^{47}$

Na opinião do referido escritor, várias são as qualidades do povo goiano, porém a principal característica "é amar o passado, a história, as tradições, sem desprezar o moderno". Ou seja, podemos pressupor que o moderno seja Goiânia, que será abordada no próximo item. O goiano da gema, como ressaltou o texto, é conformado, conciliador, é capaz de perdoar uma trapaça, é antenado ao que acontece no mundo, é justo, e honesto. Qualidades que quase se aproximam a um tipo humano ideal, ou ao homem cordial. ${ }^{48} \mathrm{O}$ goiano deste texto não tem rosto, é utópico.

Porém, no artigo intitulado "Os bons frutos da nossa árvore genealógica", os rostos dos goianos genuínos começam a aparecer e corrobora com a hipótese que levantamos páginas atrás, qual seja, que na revista Goianidade há uma valorização do grupo branco em detrimento do índio e do negro. O artigo inicia afirmando que "a sociedade goiana até a década de 1960 era basicamente tradicional, formada pelos antigos moradores das cidades construídas pelo ouro". ${ }^{49}$

Entretanto, essa sociedade tradicional viu-se ameaçada com a construção de Brasília, fazendo com que as correntes migratórias chegassem com maior rapidez. Famílias de Minas Gerais, São Paulo, do Nordeste e do Sul do país se instalaram no território goiano, principalmente na região do entorno da capital do País. Para tanto, a revista Goianidade precisava ressaltar os goianos tradicionais. Isso fica exposto na seguinte afirmação:

(...) constam de estudos genealógicos que cerca de $40 \%$ da população goiana compõem-se dos chamados "goianos tradicionais". A maioria desses goianos veio de famílias nascidas na antiga Vila Boa, Pirenópolis, Lusiânia, Silvânia, Pilar de Goiás, entre outras. Buscando mais a fundo a história da construção dessa

\footnotetext{
${ }^{47}$ IMPRENSA, op. cit., p. 162.

${ }_{48}$ "Já se disse, numa expressão feliz, que a contribuição brasileira para a civilização será de cordialidade - daremos ao mundo o 'homem cordial'. A lhaneza no trato, a hospitalidade, a generosidade, virtudes tão gabadas por estrangeiros que nos visitam, representam, com efeito, um traço definido do caráter brasileiro, na medida, ao menos, em que permanece ativa e fecunda a influência ancestral dos padrões de convívio humano, informados no meio rural e patriarcal. Seria engano supor que essas virtudes possam significar 'boas maneiras', civilidade. São antes de tudo expressões legitimas de um fundo emotivo extremamente rico e transbordante. (...) Por meio de semelhante padronização das formas exteriores da cordialidade, que não precisam ser legítimas para se manifestarem, revela-se um decisivo triunfo do espírito sobre a vida. Armado dessa máscara, o indivíduo consegue manter sua supremacia ante o social. E, efetivamente, a polidez implica uma presença contínua e soberana do indivíduo" (HOLANDA, Sérgio Buarque de. Raízes do Brasil. São Paulo: Companhia das Letras, 1999, p. 146 e 147).
}

${ }^{49}$ IMPRENSA, op. cit., p. 22. 
sociedade, observa-se que a origem das famílias consideradas tradicionais é genuinamente portuguesa. São também descendentes, em grande número, do clã Bueno, isto é, dos irmãos, filhos, sobrinhos, genros e noras de Bartolomeu Bueno da Silva. ${ }^{50}$

Isso posto, percebe-se que as famílias goianas tradicionais são descendentes de portugueses, ou da figura mítica do descobridor de Goiás, mas não de índios ou de negros, e sim de brancos. Ao contrário do que a revista tenta exaltar, como unificando a todos em torno de uma única cultura, não é isso que fica implícito. Do discurso da revista pode-se aventar que o negro e o índio, os quais foram dedicados artigos isoladamente, pertencem a goianidade, mas o que dá consistência a identidade são os brancos, com suas famílias de bem, detentoras das tradições, e de um passado idílico, ou seja, o povo original. Nesta perspectiva, Hall adverte que "a identidade é irrevogavelmente uma questão histórica. Nossas sociedades são compostas não de um, mas de muitos povos. Suas origens não são únicas, mas diversas". ${ }^{51}$

\section{Em tudo, Goiânia}

Na jovem capital de Goiás, criada na década de 1930, planejada para cinquenta mil habitantes e que de acordo como último censo possui mais de hum milhão e trezentos mil, encontra-se uma síntese do ser goiano e da história do Estado. Foi somente a partir da nova capital que a história de Goiás ganhou novo fôlego, nova página escrita sob os auspícios do moderno, edificada num terreno plano, projetada para oferecer o conforto e bem-estar a seus habitantes, ou seja, projetada para ser o oposto da Cidade de Goiás. ${ }^{52}$

Os séculos anteriores da história goiana representavam um passado tenebroso, onde as idéias de "decadência", marcada pela diminuição da produção aurífera no início do século XIX; de "isolamento", logo após a queda da mineração, que tentou ser rompido pela pecuária e pela estrada de ferro; e a de "atraso", construída na academia para designar as relações de poder entre as oligarquias na Primeira República, formavam um quadro desolador do Estado.

\footnotetext{
${ }^{50}$ IMPRENSA, op. cit., p. 22.

${ }^{51}$ HALL, op. cit., 2003, p. 30.

${ }_{52}$ "A velha Goiás era ideológica e, taticamente, representava o exemplo de como não devia ser uma capital. A Goiás Velha era vista como a antítese dos tempos, o buraco do sertão goiano, paciente em fase terminal. A velha Goiás estava velha demais para uma plástica eficiente. Suas rugas no espelho do tempo serviam de demonstração não valorativa" (CHAUL, Nars Fayad. Caminhos de Goiás: da construção da decadência aos limites da modernidade. Tese, doutorado em História. São Paulo: Universidade de São Paulo, 1995, p. 223).
} 
Através de Goiânia, Pedro Ludovico Teixeira procurou combater as idéias de "decadência" e de "atraso" que envolveram todo o percurso da História de Goiás. A recuperação dessas duas representações serviram para se construir o símbolo da modernidade em Goiás, fazendo crer que, num passe de mágica, com a nova capital, o Estado tivesse conseguido superar debilidades políticas e econômicas seculares, além de conflitos sociais e políticos que caracterizaram a sua história. ${ }^{53}$

Entretanto, os problemas não foram solucionados, "não se tornara realidade, contudo, a utopia da cidade ideal, lócus privilegiado da saúde”. Se Goiânia conseguiu oferecer melhores condições de higiene aos seus habitantes, fato que justificaria a sua construção, por outro lado, "esses objetivos foram postergados, com a priorização da irreversibilidade da cidade, em sua feição edificada, até mesmo como condição para a manutenção do poder em mãos do grupo político que a idealizara". ${ }^{54}$ Ou seja, Goiânia seria eternamente "A Capital do Futuro", tal qual o título do artigo da revista Goianidade dedicada a ela, que deprecia a cidade de Goiás em detrimento da nova capital.

Mudar a capital de Goiás para um local mais apropriado era um sonho muito antigo. Plantada entre morros, sem condições de expandir-se e numa região de clima desfavorável, Vila Boa era tida por muitos como um entrave ao progresso do Estado. ${ }^{55}$

Deste modo, Goiânia “pode assim ser encarada como a imaginação utópica da época". Representava a "perspectiva de uma nova vida, de um novo tempo, ideologicamente disseminado pela Revolução de 30". Ademais, era a "esperança de dias melhores, de ruptura com o passado, de sonho a ser conquistado, enfim, de concretização de um projeto político". ${ }^{56}$

Porém, Goiânia não podia, simplesmente, se tornar descentrada de uma história que já havia perpassado mais de dois séculos. Era necessário manter ligações com as origens do estado, e isso se materializou na estátua da figura mítica de Bartolomeu Bueno da Silva, o Bandeirante, ${ }^{57}$ doada por estudantes paulistas, que está exposta em um pedestal no centro da nova capital desde 1942.

\footnotetext{
${ }^{53}$ CHAUL, op. cit., p. 226.

${ }^{54}$ FREITAS, op. cit., p. 281.

${ }^{55}$ IMPRENSA, op. cit., p. 33.

${ }^{56}$ CHAUL, op. cit., p. 223.

${ }^{57}$ A idéia de um monumento ao Anhanguera consta desde o plano diretor de Goiânia, elaborado pelo urbanista Atílio Correia Lima em 1935 (PINHEIRO, op. cit., p. 34).
} 
Nesse sentido, no mundo das representações, o monumento ao Bandeirante, em Goiânia, doação dos paulistas, perpetua a memória de Bartolomeu Bueno, 'o descobridor de Goiás', representante dos primeiros tempos de Goiás, de uma época mítica, do fausto aurífero, da riqueza mineradora que se dizia, tinha antecedido o longo período de estagnação econômica. E São Paulo colocou o Bandeirante bem no centro da nova capital goiana, no cruzamento das avenidas Anhanguera com a Goiás - como que vindo do Leste, olhando, caminhando para o Oeste, alimentando o mito, talvez insinuando que aqui tudo começou com um intrépido paulista, que a história de Goiás é herdeira do descobridor paulista, sua antiga capital foi fundada por ele - sua nova capital inaugurando um novo tempo não poderia apagar feitos tão memoráveis. E o Bandeirante ali está, como lembrança a todos que passam pelo coração de Goiânia. ${ }^{58}$

Toda essa "ênfase nas origens", ou seja, de resgatar o mito fundador do Estado, numa cidade projetada para ser moderna, evidencia que o presente e o futuro da nova capital não se desvencilharam completamente do passado.

Os mitos fundadores são, por definição, transistóricos: não apenas estão fora da história, mas são fundamentalmente aistóricos. São anacrônicos e têm a estrutura de uma dupla inscrição. Seu poder redentor encontra-se no futuro, que ainda está por vir. Mas funcionam atribuindo o que predizem à sua descrição do que já aconteceu, do que era no princípio. Entretanto, a história, como a flecha do Tempo, é sucessiva, senão linear. A estrutura narrativa dos mitos é cíclica. Mas dentro da história, seu significado é frequentemente transformado. ${ }^{59}$

O Bandeirante que inicialmente abriu as primeiras trilhas que levavam a Goiás, agora era reverenciado pela nova capital, não no sentido saudosista de retorno àquele passado glorioso e que durou tão pouco - refiro-me à febre do ouro - mas a um futuro promissor que se descortinava aos olhos de seus habitantes. Porém, o historiador Paulo Bertran não concorda com essa opinião, uma vez que considera Goiânia um "paradigma", que "processou-se em tais condições, que arrasou, aniquilou por inteiro a noção de continuidade na história goiana". Ademais:

(...) provocou a ruptura do tecido cultural antigo, urdido com a velhice de dois séculos pregressos de história. E a ruptura daquilo que hoje se chama goianidade, um desejo de identidade que Goiânia, banalizada como qualquer outra capital brasileira, deseja assumir tardiamente, para transformar em mito, para fins diversos, econômicos e culturais. ${ }^{60}$

\footnotetext{
${ }^{58}$ PINHEIRO, op. cit., p. 35.

${ }^{59}$ HALL, op. cit., 2003, 29-30.

${ }^{60}$ BERTRAN, Paulo. “A memória consútil e a Goianidade”. In: Ciências Humanas em Revista, v.5, nº.1. Goiânia: Editora da UFG, 1994, p. 07.
} 
Ainda segundo Bertran, Goiânia deseja assumir a proeminência da identidade goiana, depois de se colocar como o novo, que não está integrado às tradições goianas. Por exemplo, não havia qualquer ligação entre os goianienses e a "memória da mineração do século XVIII, e muito pouco que aludisse ao XIX. São os óculos de Goiânia. A visão estadonovista todo-poderosa de Goiânia. Em certo sentido, a ótica do opressor". ${ }^{61}$

A revista Goianidade, por sua vez, mostra uma imagem completamente diversa da opinião do referido pesquisador. Goiânia estava integrada ao mundo, preservava suas tradições, a maioria delas que remetiam ao surgimento da própria cidade. Segundo Chaul, ao substituir "decadência" e "atraso", pela representação de "modernidade", com a ideia de progresso conquistado embutido, isso pouco se concretizou na prática. "Na realidade, o Estado como um todo continuava longe da representação alardeada. Os contrastes permaneciam! - Goiânia sustentava a imagem de modernidade, mas continuaria sendo, por muitos anos, a capital do sertão". ${ }^{62}$ Contudo, devemos nos render a opinião de Paulo Bertran quando fala sobre os óculos de Goiânia. É através desses óculos, cujas lentes vislumbram o futuro, que Goiânia, para onde se voltaram os estudiosos, os escritores, enfim, a elite intelectual de Goiás, começou a pensar a goianidade.

\section{A imprensa e os estigmas da história de Goiás}

Afirmamos páginas atrás que mais de um século de história foram suprimidos pela revista Goianidade, período este que compreende o início do século XIX até a década de 1930. Na oportunidade aventamos que isso era o reflexo da falta de pesquisa acadêmica que privilegiasse o referido período; porém, podemos aferir outra hipótese: a de que neste espaço de tempo se formou os estigmas da História de Goiás, quais sejam, a decadência, o isolamento e o atraso. Ou seja, do apogeu aurífero, as páginas da Goianidade salta para se deslumbrar com a moderna Goiânia. Nesta perspectiva “(...) a imprensa veicula idéias, conceitos, propostas que são engendradas pela práxis social dos grupos cujos interesses defende constituindo-se, ela própria, num momento dessa prática". ${ }^{63}$ Ademais, segundo a historiadora Maria Helena Rolim Capelato, a leitura dos discursos veiculados na imprensa:

\footnotetext{
${ }^{61}$ BERTRAN, op. cit., p. 07.

${ }^{62}$ CHAUL, op. cit., p. 231.

${ }^{63}$ VIEIRA, M. do Pilar de A., et al. "Imprensa como fonte para a pesquisa histórica". In: Projeto História nº 3. São Paulo: PUC, 1984, p. 48.
} 
(...) permite acompanhar o movimento das idéias que circulam na época. A analise do ideário e da prática política dos representantes da imprensa revela a complexidade da luta social. Grupos se aproximam e se distanciam segundo as conveniências do momento; seus projetos se interpenetram, se mesclam e são matizados. Os conflitos desencadeados para a efetivação de diferentes projetos se inserem numa luta mais ampla que perpassa a sociedade por inteiro. O confronto das falas, que exprimem idéias e práticas, permite ao pesquisador captar, com riqueza de detalhes, o significado da atuação de diferentes grupos que se orientam por interesses específicos. ${ }^{64}$

Quais interesses permearam o processo de feitura da revista Goianidade? Para quem a revista estava endereçada? Como a história de Goiás foi contada e com que objetivo foi pensada e escrita na revista? Todos esses questionamentos convergem para os quatro conceitos que pautam a historiografia goiana, e que foram brevemente abordados no item anterior, quais sejam, a decadência, o isolamento, o atraso e a modernidade. Nesse ínterim, os três primeiros conceitos foram silenciados em função de um objetivo maior, o de valorizar o moderno, que se materializou nas ruas, avenidas e prédios de Goiânia.$^{65}$ Esse quadro também nos inquieta no sentido de que a revista presume que a história de Goiás não é digna de nota antes da década de 1930, somente aquela que remonta ao apogeu da produção aurífera, um período de fausto e abundância que remete àqueles tempos míticos. Isso fica evidente quando argumentamos páginas atrás, a respeito dos três maiores líderes do Estado de acordo com a revista.

Não obstante, o período histórico que foi suprimido pela revista foram os que permearam os conceitos de decadência, isolamento, e atraso. Portanto, os denominaremos de estigmas, uma vez que os mesmos foram banidos das páginas da Goianidade, possivelmente por considerá-los antagônicos ao seu objetivo, qual seja, o de resgatar o sentimento de orgulho de ser goiano. Partindo desse pressuposto, a história de Goiás não poderia ser contada pelo viés desses três estigmas; a ordem era de reescrevê-la, e ao fazê-lo a mesma só ganhou sentido e forma com os auspícios da modernidade.

Portanto, há que se considerar um imbricado jogo de interesses: de um lado os editores da revista se empenharam em narrar a história de Goiás adicionando a ela ingredientes que ambicionaram contagiar o público que porventura viessem a folheá-la; de outro, a história estigmatizada de Goiás,

\footnotetext{
${ }^{64}$ CAPELATO, Maria Helena Rolim. Imprensa e História do Brasil. São Paulo: Contexto/EDUSP, 1988, p. 34.

${ }^{65}$ Isso fica evidente na seguinte constatação, dos vinte e oito artigos que integram a revista Goianidade, vinte deles se remetem direta ou indiretamente a Goiânia.
} 
cujos ruídos surgem dos subterrâneos ${ }^{66}$ para onde as páginas da Goianidade os relegou. Nesta perspectiva, abordaremos os três estigmas da história de Goiás fazendo um contraponto com o discurso da referida revista, a começar pela decadência. A revista Goianidade cita brevemente este período e o que ele ocasionou como colocando fim a febre do ouro, e resumindo como foi a história do Estado até as primeiras décadas do século XX:

(...) Depois do período de glória veio a decadência da mineração. (...) Entre outros fatores, a decadência do ciclo do ouro produziu o esvaziamento, o empobrecimento e o isolamento cultural dos núcleos populacionais. (...) Desemprego, vícios, más condições de alimentação, de higiene, falta de educação, enfim, os centros mineradores eram o retrato da degeneração. ${ }^{67}$

Percebe-se que a decadência e o isolamento são tratados como sinônimos. $\mathrm{O}$ isolamento do Estado ocorreu devido a decadência. Terminava melancolicamente este capítulo da História de Goiás. Esse passado que remetia a diversos antagonismos como riqueza - desemprego, abundância - falta de alimentação, e, por conseguinte diversos adjetivos desabonadores.

A história da decadência, como tema historiográfico está pautado basicamente em duas fontes, de que se serviram os pesquisadores, a saber, os relatórios dos viajantes estrangeiros que estiveram em Goiás nas primeiras décadas do século XIX e os relatórios dos capitães/presidentes da capitania/ província. Essas, por sua vez, ajudaram a cristalizar a idéia de que Goiás, logo após o fim da mineração viveu um período de trevas. Porém, nos estudos mais recentes, ao contrário do que a historiografia perpetuou, a decadência da mineração não impediu o "desenvolvimento social e cultural", mas apenas deu "lugar a culturas e formas de socialização diferentes daquelas conhecidas no auge da produção aurífera ou daquelas características da modernidade capitalista".$^{68}$ Outrossim, de acordo com Chaul:

(...) quanto ao tema da decadência, cabe observar que o termo, decantado pelos viajantes, não encontrava correspondência na sociedade local, distante ainda dos moldes de produção capitalista, que os europeus ansiavam por ver no sertão de Goiás. A sociedade local não se via indolente, ociosa e muito menos

\footnotetext{
${ }^{66}$ Cf. POLLAK, Michel. "Memória, esquecimento, silêncio”. In: Estudos Históricos. Vol. 2, n. 3. Rio de Janeiro, 1989.

${ }^{67}$ IMPRENSA, op. cit., p. 17.

${ }^{68}$ ASSIS, Wilson Rocha. Os Moderados e as Representações de Goiás n'a Matutina Meiapontense (1830-1834). Dissertação, mestrado em História. Goiânia: Universidade Federal de Goiás, 2007, p. 20.
} 
decadente. Apenas orientava-se por outros níveis de preocupações e buscava satisfazer necessidades vitais à sua maneira. ${ }^{69}$

Os dois autores que ora citamos fazem parte de uma corrente historiográfica revisionista, cujo intuito era rever a forma com que o conceito de decadência foi usado pela historiografia tradicional. A partir das mesmas fontes que serviram para embasar o discurso da decadência, esses autores tinham por objetivo desconstruí-la. Ou seja, em Goiás não houve decadência, porque eles não se viam com decadentes, o olhar do europeu não compreendeu a lógica da sociedade goiana no período.

Do mesmo modo, o isolamento do estado era motivo de preocupação. Passado o apogeu do ouro "o número de imigrantes também diminuiu, cessando quase que por completo". ${ }^{70}$ Com isso, Goiás se isolou, muitos habitantes se deslocaram para outros lugares, e os poucos que restaram ficaram reféns do marasmo sem nenhuma conexão com o mundo além das fronteiras goianas. Era essa a imagem que a revista queria passar, porém, esqueceram de um personagem muito interessante da história de Goiás: o tropeiro. Mesmo com o "declínio da mineração e o gradativo desenvolvimento da atividade agro-pastoril", o tropeiro continuou com a sua mesma função, qual seja, o de abastecer Goiás "com gêneros, víveres, notícias e novidades, ligando esta província, mesmo que precariamente, aos grandes centros do país, viabilizando, abrilhantando e amenizando a vida no coração do Brasil". ${ }^{71}$

A economia goiana continuou necessitando de um influxo complementar, as estradas não receberam melhorias, as distâncias não encurtaram. Desse modo o tropeiro continuou seu mister, transportando mercadorias e abastecendo Goiás, intermediando os negócios entre arraiais, povoados, vilas, distritos, municípios e províncias. ${ }^{72}$

A figura do tropeiro foi completamente silenciada pela Goianidade. Nem mesmo no artigo "Caminhos da Prosperidade", que faz um balanço das estradas em Goiás, desde os cavalos utilizados por Bartolomeu Bueno até as rodovias pavimentadas há uma mera menção sequer a esse personagem. Os caminhos de Goiás foram desbravados primeiro pelo intrépido bandeirante e depois pela modernidade que os cortou com o asfalto. Ao enterrar o tropeiro e a sua

\footnotetext{
${ }^{69}$ CHAUL, op. cit., p. 229.

${ }^{70}$ IMPRENSA, op. cit., p. 18.

${ }^{71}$ GUMIERO, Maristela Porfírio da Paz. Os Tropeiros na História de Goiás - Séculos XVIII E XIX. Dissertação, mestrado em História. Goiânia: Universidade Federal de Goiás, 1991, 95.
}

${ }^{72}$ GUMIERO, op. cit., 95. 
importância para interligar Goiás com outras regiões do país, a revista cumpre com o seu propósito: não havia história neste lugar antes de 1930. Neste caso, o século XIX foi marcado por um período sombrio que não necessitava ser revisitado, o importante era o futuro. Por esses caminhos asfaltados já passaram os dormentes da estrada de ferro, que trouxeram o progresso, e que, possivelmente, apagaram as marcas de tantas tropas e boiadas que cruzaram esses sertões. ${ }^{73}$

O último estigma refere-se ao atraso, que Francisco Itami Campos utilizou para analisar as relações entre as oligarquias goianas na Primeira República. Para ele, "o atraso era uma forma de controle sócio-político", como no exemplo da via-férrea em Goiás, quando vários políticos goianos dificultaram a sua implementação. A estrada de ferro "traria uma aproximação do Estado com o ainda incipiente mercado nacional e com isso seria quebrado o isolamento, em que vivia o goiano". ${ }^{74}$

No breve histórico sobre Goiânia não há nenhuma menção as grandes oligarquias que se revezavam no poder na Cidade de Goiás, tais como os Bulhões e os Caiados. ${ }^{75} \mathrm{~A}$ Goianidade, entretanto, se limita a explorar a figura de Pedro Ludovico e o seu ideal em mudar a capital do Estado creditando a isso às péssimas condições de higiene que os vilaboenses usufruíam. ${ }^{76}$

A revista Goianidade, portanto, deixa imensa lacuna sobre a História de Goiás, e podemos refletir sobre isso de duas formas: por um lado a maior parte da pesquisa acadêmica que abordou a desmistificação dos estigmas foi realizada a posteriori; por outro, a revista selecionou com extremo cuidados os momentos históricos que julgou relevantes para construir a sua narrativa, cuja intenção era exaltar o orgulho de ser goiano, objetivando, desse modo, estabelecer uma identidade cultural para o Estado.

\section{Considerações finais}

Neste artigo procuramos discutir a construção de uma identidade cultural para Goiás a partir da revista Goianidade, de 1992, editada pela Associação

\footnotetext{
${ }^{73}$ Sobre a implantação da estrada de ferro em Goiás, e a conjuntura do estado durante a Primeira República ver: BORGES, Barsanufo Gomides. O Despertar dos Dormentes. Dissertação, mestrado em História. Goiânia: Universidade Federal de Goiás,1982.

${ }^{74}$ CAMPOS, Francisco Itami. Coronelismo em Goiás. Goiânia: Ed. UFG, 1983, p. 64.

${ }^{75}$ Em CHAUL, Nasr Fayad (coord.). Coronelismo em Goiás: Estudos de casos e famílias. Goiânia: Ed. Kelps, 1998; há três interessantes estudos sobre o coronelismo que abordam a literatura, o cotidiano na cidade de Morrinhos e a família Caiado, respectivamente.

${ }^{76}$ IMPRENSA, op. cit., p. 33-35.
} 
Goiana de Imprensa, em uma única edição, pautado nos pressupostos defendidos por Stuart Hall. Feita em Goiânia, a revista Goianidade tinha a pretensão de delinear uma identidade cultural para Goiás, porém, partindo da jovem capital. o que será que esses óculos consideraram como sendo tipicamente goiano? o que o foco de suas lentes deixou de observar, uma vez que mais de $90 \%$ dos artigos da referida revista remetem a Goiânia?

Igualmente, à decadência, ao isolamento e ao atraso logo se interpôs a modernidade, como tomando para si as rédeas descontroladas da História de Goiás. Era preciso reinventar Goiânia, a jovem capital tão descriminada no desastre com o césio. Era preciso tecer fios consistentes que se entrelaçariam numa velha roda de fiar: o orgulho ferido, e a certeza num progresso vindouro, que aos poucos se descortinava diante dos olhos nas imponentes fotografias da revista Goianidade. As estradas pavimentadas que chegaram mais longe que as tropas, mais velozes que o trem de ferro e mais destemidas que o intrépido bandeirante davam o tom exato da opulência daquele momento.

Artigo recebido para publicação em 03/06/2017

Artigo aprovado para publicação em 22/09/2017 